\title{
FLORISTIC RELATIONSHIPS OF LOWLAND RAINFOREST PHANEROGAMS OF NEW ZEALAND
}

\author{
J. W. DAWSON
}

(Accepted for publication 16.9.1983)

\begin{abstract}
Dawson, J. W. (Botany Department, Victoria University of Wellington, Wellington, New Zealand) 1986. Floristic relationships of lowland rainforest phanerogams of New Zealand. Telopea 2(6): 681-695 - Floristic relationships are examined for woody and epiphytic herbaceous genera of the New Zealand lowland rainforest. The 80 genera are divided into five categories: (1) gymnosperms; $(2,3,4)$ non-endemic angiosperms; (5) endemic genera and genera of uncertain status. Climatic preference is the basis for division of the non-endemic genera: (2) lowland tropical; (3) lowland and montane tropical to Australian temperate; (4) montane tropical and lowland south temperate. The species of angiosperms are grouped into standard leaf-size classes. Patterns observed in correlations of leaf size, latitude and growth form are shown. Maps illustrate the Australasian distributions of the non-endemic genera; occurrences of New Zealand genera in South America, the Pacific and South Africa are noted. Comparisons among the non-endemic genera revealed the following trends: the number of species per genus is lowest in lowland tropical genera (1.4 per genus) and greatest in the montane tropical and south temperate (4.2 per genus); about one-third of the species in lowland tropical genera are microphyllous, in the other two categories about two-thirds of the species are microphyllous; lowland tropical genera (category 2) occur only in rainforest, of species in category 3,28\% occur also in non-forest habitats, and in category 4, 48\%; $27 \%$ of species in category 2 belong to genera of probable southern origin, for category $4,90 \%$ of species. Contrary to these trends is the greater frequency of specialized growth forms (lianes and epiphytes) in category $4(36 \%)$ compared with $16 \%$ of species in category 2 . A possible explanation for this trend is given.
\end{abstract}

\section{INTRODUCTION}

Newcomers to New Zealand, botanists and laymen alike, are often struck by the 'tropical' appearance, unexpected in temperate latitudes, of the New Zealand lowland rainforest*. This 'tropical' impression depends not so much on the presence of species belonging to tropical genera, as on a profusion of specialized growth forms of types often considered to be characteristic of and peculiar to tropical forests - large tree ferns are common and there is also a tall palm of similar form in milder sites of both islands; woody and herbaceous vines are abundant as are vascular epiphytes, which range from humus-accumulating and water-storing nests, through small shrubs to hemi-epiphytic shrubs and a few tree 'stranglers'. Furthermore, the New Zealand rainforest with its conifer and angiosperm emergents and canopy and subcanopy strata is similar in structure to tropical forests.

The structure and growth forms of the forest have been considered in earlier papers (Dawson \& Sneddon 1969, Dawson 1962, 1966, 1967, 1970) and on this occasion its floristic relationships will be reviewed $\dagger$.

\footnotetext{
*Nothofagus forest is not included here as it is predominantly montane and lacks most of the 'tropical' features of the lowland rainforest.

$\uparrow$ The only herbaceous species included are epiphytes.
} 


\section{OBSERVATIONS}

The genera represented will be considered in the following categories:

(1) Gymnosperms.

(2) Angiosperm genera predominantly lowland in the tropics and restricted in Australia to the tropical/subtropical north-east or extending as far as central New South Wales.

(3) Angiosperm genera lowland or lowland and montane in the tropics and extending along the Australian east coast, and sometimes through the south, with some genera reaching Tasmania.

(4) Angiosperm genera predominantly montane in the tropics or lowland south temperate and where present in Australia mostly in the south-east.

(5) Angiosperm genera endemic to New Zealand or of uncertain status or relationships.

\section{Group 1. Gymnosperms (Fig. 1)} 1972).

For the Podocarpaceae the genera are as defined by de Laubenfels (1969,

Conifers are prominent in most New Zealand rainforests, particularly the tall emergents, Agathis australis (northern only), Dacrydium cupressinum and Dacrycarpus dacrydioides. Most of the genera or their putative ancestors have a fossil record extending back to the Mesozoic, so most if not all, would have been present on Gondwanaland before New Zealand and other continental fragments separated from it. There seems no need, then, to invoke long-distance dispersal to explain the present distribution of conifers in the Australasian region and, indeed, their virtual restriction to the Australian continent and adjacent continental islands supports the view that gymnosperms in general have limited dispersal ability. Fiji is here considered to be a continental island as, although it is largely volcanic, it has some continental rocks and is currently considered to have been displaced eastwards by crustal extension in the South Fiji Basin.

The presence of one species of Podocarpus in each of Tonga and Samoa might be explained by the facts that these islands are not very distant from Fiji and that the seeds of the Podocarpaceae, having fleshy tissues associated with them, are attractive to birds and so have somewhat better dispersal ability than those of other conifers.

Agathis has some species in the tropical lowlands with others ranging up to about $2000 \mathrm{~m}$. The New Zealand species is restricted to the northern half of the North Island.

Dacrycarpus, Dacrydium B* (D. cupressinum only in New Zealand) and Podocarpus also have some lowland species in the tropics, but with montane species as well, ranging to altitudes of $3000-4000 \mathrm{~m}$. In New Zealand, most of the species of these genera range throughout the country and none are restricted to the northern North Island. One species of Podocarpus is a shrub often found above the tree-line.

Phyllocladus and Prumnopitys are montane in the tropics, Dacrydium $\mathrm{C}^{*}$ does not occur there and Libocedrus only just (New Caledonia). Most of the

\footnotetext{
*In a recent revision, Quinn (1982) restricts Dacrydium to Dacrydium B and subdivides Dacrydium $\mathrm{C}$ into three new genera: Halocarpus, endemic to New Zealand with four species; Lagarostrobus, with one New Zealand and one Tasmanian species; and Lepidothamnus, with one New Zealand and one Chilean species.
} 


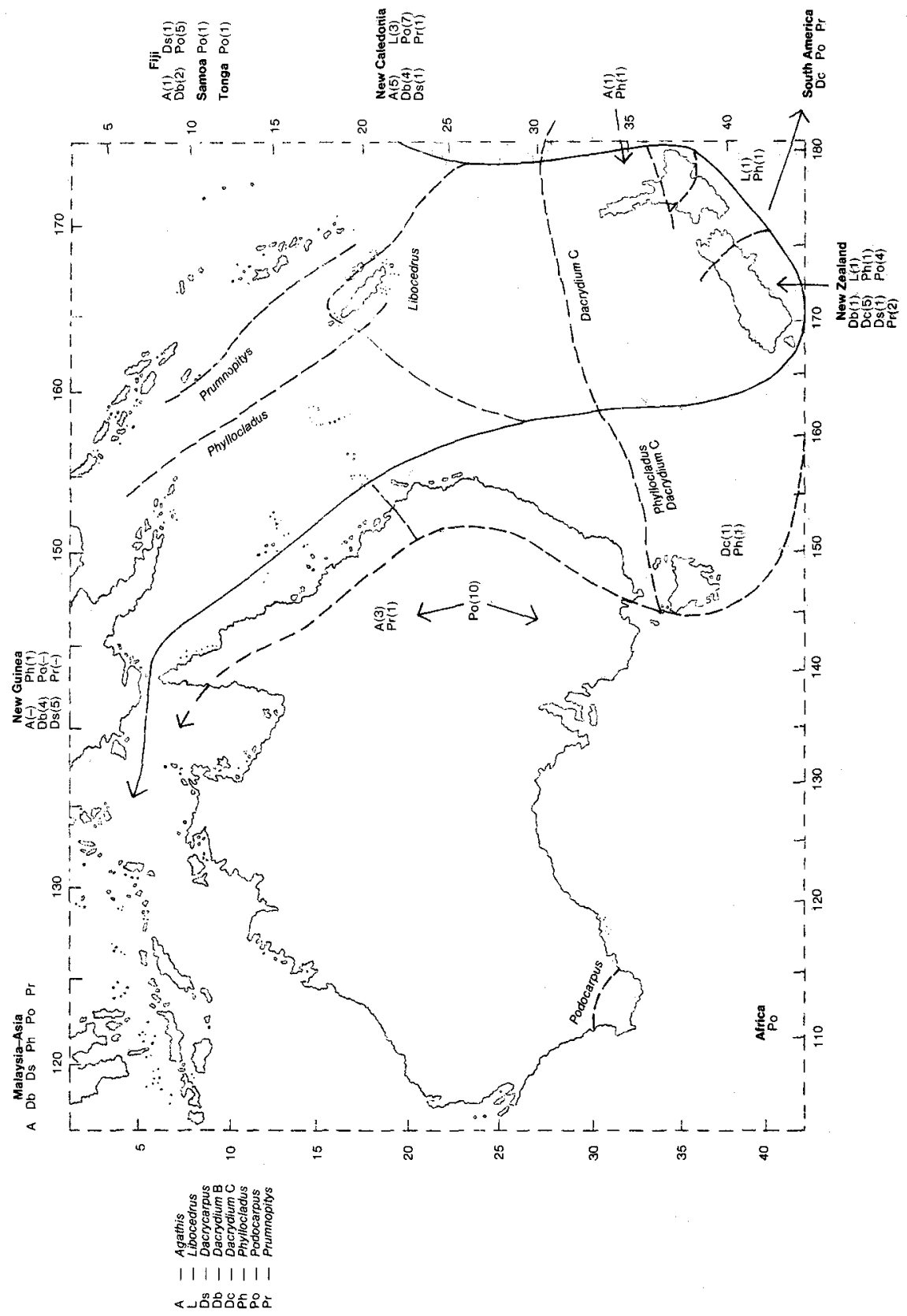

Fig. 1. Distribution of gymnosperm genera represented in New Zealand. The New Zealand species in each block reach their southern limits in the zones indicated. 
species of these genera range through New Zealand except for one species of Phyllocladus and one of Dacrydium restricted to the northern North Island, and one of Libocedrus, which reaches the northern tip of the South Island. The other species of Libocedrus is montane, while one species of Phyllocladus and two of Dacrydium $\mathrm{C}$ are shrubs often above the tree-line.

All the conifer genera represented in New Zealand are likely to have originated in the southern hemisphere.

\section{Group 2. Lowland tropical angiosperm genera (Fig. 2)}

Eighteen genera with 25 New Zealand species are included here, giving a low average number of species per genus of 1.4. However, it is remarkable that these genera should be present in New Zealand at all and even more remarkable that they were able to survive the Pleistocene glaciations.

The species are grouped according to Raunkiaer's leaf-size categories with the addition of a notophyll (small mesophyll) class following Webb (1959). The southern limit for each species is also recorded.

Macrophyll (12\%). Freycinetia banksii (46 ); Pennantia baylisiana (Fig. 3; $\left.3 \mathrm{~K}^{*}: 34^{\circ}\right)$; Meryta sinclairii $\left(3 \mathrm{~K}: 34^{\circ}\right.$ and Hen and Chicken Islands: $\left.36^{\circ}\right)$.

Mesophyll (24\%). Alectryon grandis (3K:34 ); Corynocarpus laevigatus $\left(44^{\circ}\right)$; Dysoxylum, spectabile (Fig. 3; 40³0'); Paratrophis smithii $\left(3 \mathrm{~K}: 34^{\circ}\right)$; Macropiper excelsum, $\left(44^{\circ}\right)$; Schefflera digitata $\left(47^{\circ}\right)$.

Notophyll (32\%). Alectryon excelsus $\left(44^{\circ}\right)$; Beilschmiedia tarairi (Fig. 3; 38 $)$; Litsea calicaris $\left(38^{\circ}\right)$; Melicope ternata $\left(41^{\circ} 30^{\prime}\right)$; Pennantia corymbosa (Fig. 3; $\left.46^{\circ}\right)$; Planchonella novozelandica $\left(38^{\circ}\right)$; Tecomanthe speciosa $\left(3 \mathrm{~K}: 34^{\circ}\right)$; Vitex lucens (Fig. 3; 39³0').

Microphyll (20\%). Ackama rosifolia (36 ); Beilschmiedia tawa (Fig. 3; 42 $)$; Geniostoma ligustrifolium $\left(41^{\circ} 30^{\prime}\right)$; Paratrophis banksii $\left(41^{\circ}\right)$; Peperomia urvilleana $\left(41^{\circ}\right)$.

Nanophyll (12\%). Melicope simplex $\left(46^{\circ}\right)$; Paratrophis microphylla $\left(46^{\circ}\right)$; Peperomia tetraphylla $\left(38^{\circ}\right)$.

It can be seen that species with leaves of 'tropical' size, mesophylls and larger, make up $38 \%$ of the total, and species with microphylls or less, considered characteristic of temperate climates, account for $32 \%$. In those genera with more than one species, reduction in leaf size correlates with increase in latitude. This is summarized in Table 1 and illustrated for Pennantia and Beilschmiedia in Fig. 3.

These leaf reduction sequences presumably reflect adaptations to cooler conditions, although no species has occupied colder non-forest habitats. Such evolution of hardier forms would be one factor in the survival of the genera concerned. For species in these and other genera with mesophylls or larger it is hypothesized that most survived each glaciation in the far north of the country, the land there being more extensive than now as a result of lowered sea level,

* Three Kings Islands. 


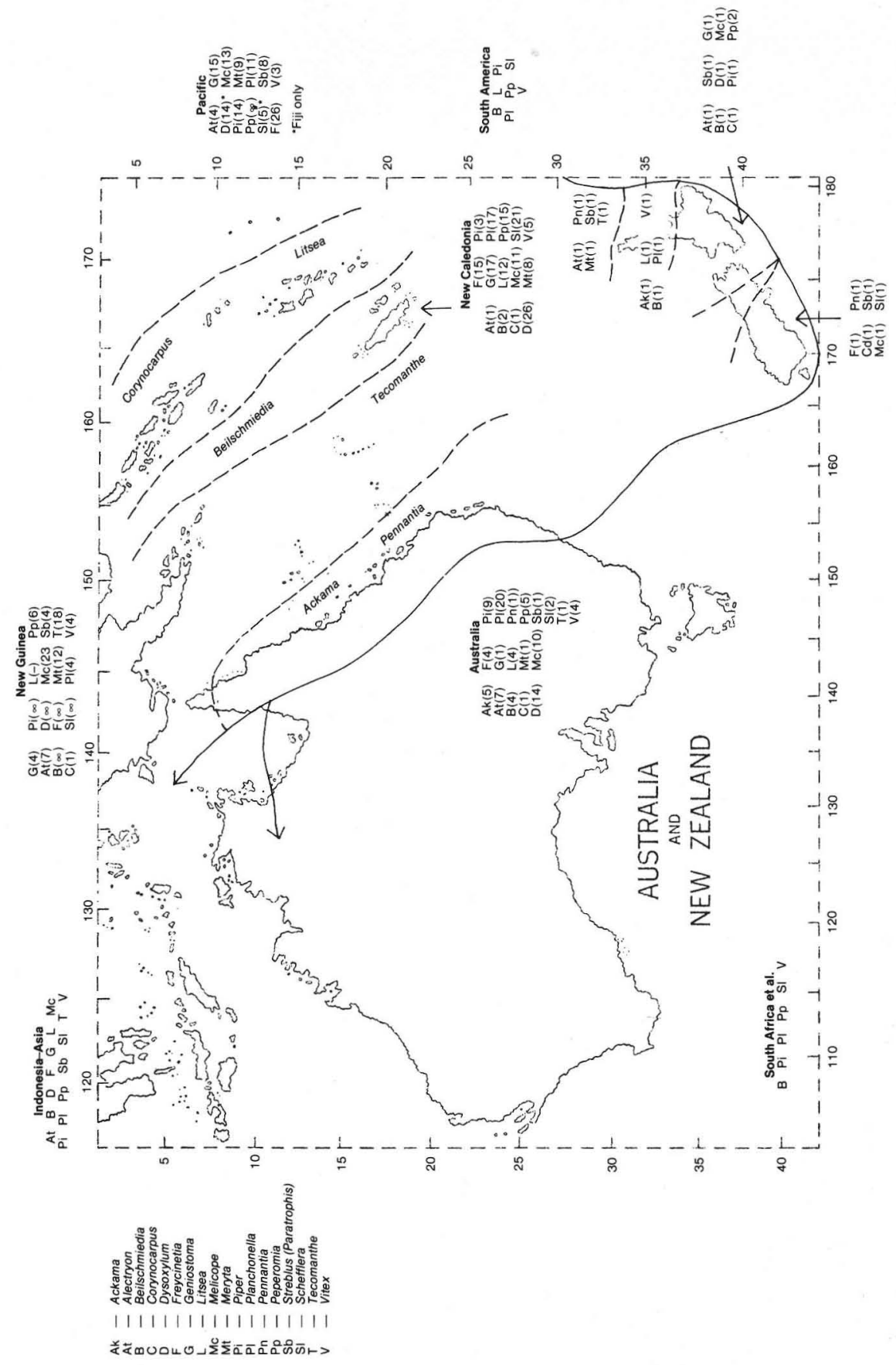

Fig. 2. Distribution of Group 2 angiosperm genera. The New Zealand species in each block reach their southern limits in the zones indicated. 


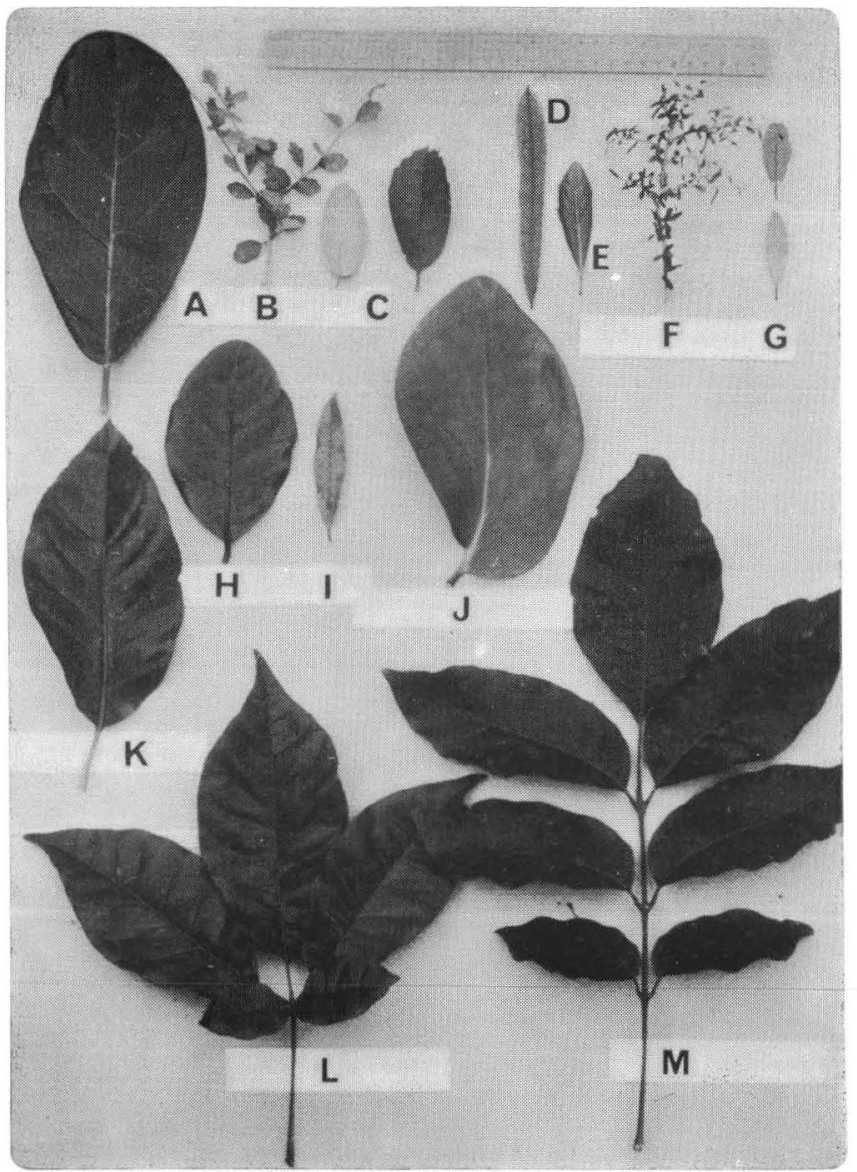

Fig. 3. Leaves of 10 selected rainforest species. Pennantia:

A - P. baylisiana

B - P. corymbosa (juvenile) $\mathrm{C}-P$. corymbosa (adult)

Elaeocarpus:

$\mathrm{D}-E$. dentatus (juvenile)

$\mathrm{E}-\mathrm{E}$. dentatus (adult)

$\mathrm{F}-$ E. hookerianus (juvenile)

$\mathrm{G}-E$. hookerianus (adult)

Beilschmiedia:

$\mathrm{H}-$ B. tarairi

I - B. tawa

$\mathbf{J}$ - Griselinia lucida

$\mathrm{K}$ - Coprosma grandifolia

L-Vitex lucens

M - Dysoxylum spectabile. (Scale in $\mathrm{cm}$ )

TABLE 1. CORRELATION OF LEAF SIZE WITH LIMITS OF LATITUDE IN GENERA OF MORE THAN ONE SPECIES.

\begin{tabular}{|c|c|c|c|c|c|}
\hline \multirow{2}{*}{$\begin{array}{l}\text { Genus } \\
\text { species }\end{array}$} & \multicolumn{5}{|c|}{${ }^{\circ} \mathrm{S}$ latitude limit by leaf-size categories } \\
\hline & Macrophyll & Mesophyll & Notophyll & Microphyll & Nanophyll \\
\hline $\begin{array}{l}\text { Pennantia } \\
\text { baylisiana } \\
\text { corymbosa }\end{array}$ & $34^{\circ}$ & & $46^{\circ}$ & & \\
\hline $\begin{array}{l}\text { Paratrophis } \\
\text { smithii } \\
\text { banksii } \\
\text { microphylla }\end{array}$ & & $34^{\circ}$ & & $41^{\circ}$ & $46^{\circ}$ \\
\hline $\begin{array}{c}\text { Melicope } \\
\text { ternata } \\
\text { simplex }\end{array}$ & & & $41^{\circ} 30^{\prime}$ & & $46^{\circ}$ \\
\hline $\begin{array}{l}\text { Alectryon } \\
\text { grandis } \\
\text { excelsus }\end{array}$ & & $34^{\circ}$ & $44^{\circ}$ & & \\
\hline $\begin{array}{l}\text { Beilschmiedia } \\
\text { tarairi } \\
\text { tawa }\end{array}$ & & & $38^{\circ}$ & $42^{\circ}$ & \\
\hline
\end{tabular}


and particularly on small offshore islands where milder oceanic conditions would prevail. Some of these larger leaved species have remained in the far north and on the Three Kings Islands in particular; several are nearly extinct in nature. Others migrated southwards following climatic recovery, with Schefflera digitata and Freycinetia banksii reaching the southern end of the country. With these last two, however, the possibility of survival elsewhere, such as the north-west of the South Island, considered by some to have provided a forest refuge, must also be considered.

Mildenhall (1980), in a useful review of New Zealand palaeobotany based on microfossils, states in relation to the Pleistocene: 'Recurrent glaciations markedly changed the vegetation and landscape and the last remnants of tropical and subtropical taxa disappeared'. It seems to me that some of the genera still present in New Zealand have just as good a claim to be considered 'tropical' as such genera as Cupania and Anacolosa, which were among those Mildenhall had in mind. Dysoxylum spectabile, for instance, with a probable record in New Zealand for the genus from the Miocene, is a dominant in forests near the sea as far south as $41^{\circ} 30^{\prime}$. With its compound leaves with large leaflets (Fig. 3) and its cauliflory, if it were transplanted to the lowland tropics it would not seem at all out of place among other species of the genus growing there. This also is a good example of the uncertainties of using plant fossils as indicators of past climates, in some cases at least. If Dysoxylum spectabile had also become extinct in New Zealand, then the finding of its large leaflets as fossils in combination with the general lowland tropical distribution of the genus, would probably lead to the conclusion that the climate of the period concerned was much warmer than that under which $D$. spectabile now thrives.

Most of the genera in this section have a fossil record in New Zealand extending back to the Tertiary, but none with any certainty to the Cretaceous (except possibly Lauraceae from macrofossils), thus they probably reached New Zealand after its separation from Gondwanaland. How was this achieved?

Over half the genera - Alectryon, Freycinetia, Geniostoma, Melicope, Meryta, Peperomia, Piper (Macropiper)*, Planchonella, Streblus (Paratrophis)*, Vitex - have some oceanic species extending as far as Tahiti and/or Hawaii, so they could presumably have reached New Zealand by long-distance dispersal. The other genera - Ackama, Beilschmiedia, Corynocarpus, Dysoxylum, Litsea, Pennantia, Schefflera, Tecomanthe - have no fully oceanic species so it is less likely that they would have been able to reach New Zealand over a wide ocean gap.

In the early Tertiary, land in the New Zealand region was peneplained and reduced by marine transgression, but at no time did it disappear completely. This may have been so also for the continental Lord Howe Rise and Norfolk Ridge extending from New Zealand as far as New Caledonia, in which case 'island hopping' at least would have been a possibility. Certainly, if it is true that Araucaria has very limited dispersal ability, then the presence of a distinctive species of that genus on volcanic Norfolk Island, halfway between New Zealand and New Caledonia, would imply continuous, if changing, land in the vicinity throughout the Tertiary. Perhaps the crustal pressures that uplifted New Zealand in the later Tertiary also resulted in the downwarping of the ridges to the north.

\footnotetext{
* Opinions differ on generic limits. The wider view is followed here.
} 
The present distributions of Ackama, Alectryon, Corynocarpus, Meryta, and Pennantia suggest a southern, perhaps Australasian, origin. The remaining genera are pantropical or centred in tropical Asia.

Only a few of the species in this group have specialized growth habits: Tecomanthe speciosa is a twining liane, now represented in nature on the Three Kings by only one plant; the abundant Freycinetia banksii is a root-climbing liane; and the two peperomias are often low epiphytes on tree trunks.

\section{Group 3. Lowland to montane tropical angiosperm genera (Fig. 4)}

Included in this category are 13 genera with 51 New Zealand species, giving an average of 4 species per genus. However, if only the 37 forest species are considered the average drops to 3 .

The leaf-size groupings for the forest species are as follows:

Notophyll (38\%). Elaeocarpus dentatus (Fig. 3; 46 ); Hedycarya arborea $\left(46^{\circ}\right) ;$ Myrsine oliveri $\left(3 \mathrm{~K}: 34^{\circ}\right) ; M$. salicina $\left(42^{\circ} 30^{\prime}\right)$; Pittosporum huttonianum $\left(37^{\circ}\right)$, P. ellipticum $\left(37^{\circ}\right)$, P. umbellatum $\left(39^{\circ}\right)$, P. kirkii $\left(39^{\circ}\right)$, $P$. ralphii $\left(40^{\circ}\right), P$. eugenioides $\left(46^{\circ}\right), P$. colensoi $\left(47^{\circ}\right)$; Quintinia acutifolia $\left(43^{\circ}\right)$, Q. serrata $\left(39^{\circ}\right)$; Ripogonum scandens $\left(47^{\circ}\right)$.

Microphyll (46\%). Elaeocarpus hookerianus (Fig. 3; 47); Muehlenbeckia australis $\left(47^{\circ}\right)$; Myrsine australis $\left(47^{\circ}\right)$, M. chathamica $\left(47^{\circ}\right)$; Parsonsia heterophylla $\left(47^{\circ}\right)$; Passiflora tetrandra $\left(44^{\circ}\right)$; Pittosporum fairchildii $\left(3 \mathrm{~K}: 34^{\circ}\right), P$. virgatum $\left(35^{\circ}\right)$, $P$. pimeleoides $\left(35^{\circ}\right)$, P. turneri $\left(39^{\circ}\right), P$. crassifolium $\left(39^{\circ}\right), P$. patulum, $\left(41^{\circ}\right), P$. cornifolium $\left(41^{\circ}\right), P$. tenuifolium $\left(46^{\circ}\right)$; Quintinia elliptica $\left(39^{\circ}\right)$; Syzygium maire $\left(41^{\circ}\right)$; Drymoanthus adversus $\left(47^{\circ}\right)$.

Nanophyll (13.5\%). Bulbophyllum tuberculatum (41 ${ }^{\circ}$; Dendrobium cunning-

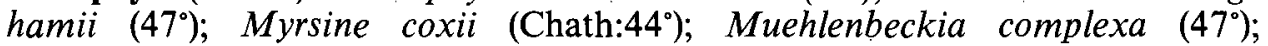
Parsonsia capsularis $\left(46^{\circ}\right)$.

Leptophyll (2.5\%). Bulbophyllum pygmaeum (47).

Leaves are considerably smaller in this group than those of Group 2, suggesting an adaptation to cooler conditions and a greater ability to survive glaciations. There are no mesophyll or larger sizes and microphylls and smaller leaves account for more than $60 \%$ of the total.

With fewer leaf-size categories, latitudinal patterns are not so easily discernible, although a correlation between decreasing leaf size and increasing latitude is apparent in Myrsine and Bulbophyllum. In the other genera with two or more species there are no clear latitudinal trends, although in Pittosporum and Muehlenbeckia, as well as Myrsine, the non-forest species, growing at colder higher altitudes or in seasonally cold lowland sites, have smaller leaves than the forest species.*

\footnotetext{
* This correlation between decreasing leaf size and decreasing temperature has been noted in rainforests elsewhere, as has a correlation between decreased leaf size and increased orders of branching. Thus the numerous and conspicuous small-leaved, densely branching ('divaricating') shrubs and juvenile trees in the New Zealand flora, belonging to rainforest genera (Coprosma, Myrsine, Pseudopanax, Pennantia (Fig. 3), Pittosporum, Elaeocarpus (Fig. 3), etc.), may represent the extreme state of these two trends induced by Pleistocene cold. McGlone \& Webb (1981) have observed frost tolerance in a number of cultivated divaricating shrub species and also suggest frost tolerance as an explanation for divaricating juveniles - 'The transition of divaricating juveniles to non-divaricating adult plants often occurs in the height range of three to four metres ... The transition from the juvenile form at this height can be explained by the climatic hypothesis, as it ensures that plants have a deep, well-established root system and that their foliage is well above the height of damaging ground frosts. The divaricating juvenile form may thus enable forest trees to act as colonisers in forest margin habitats'.
} 


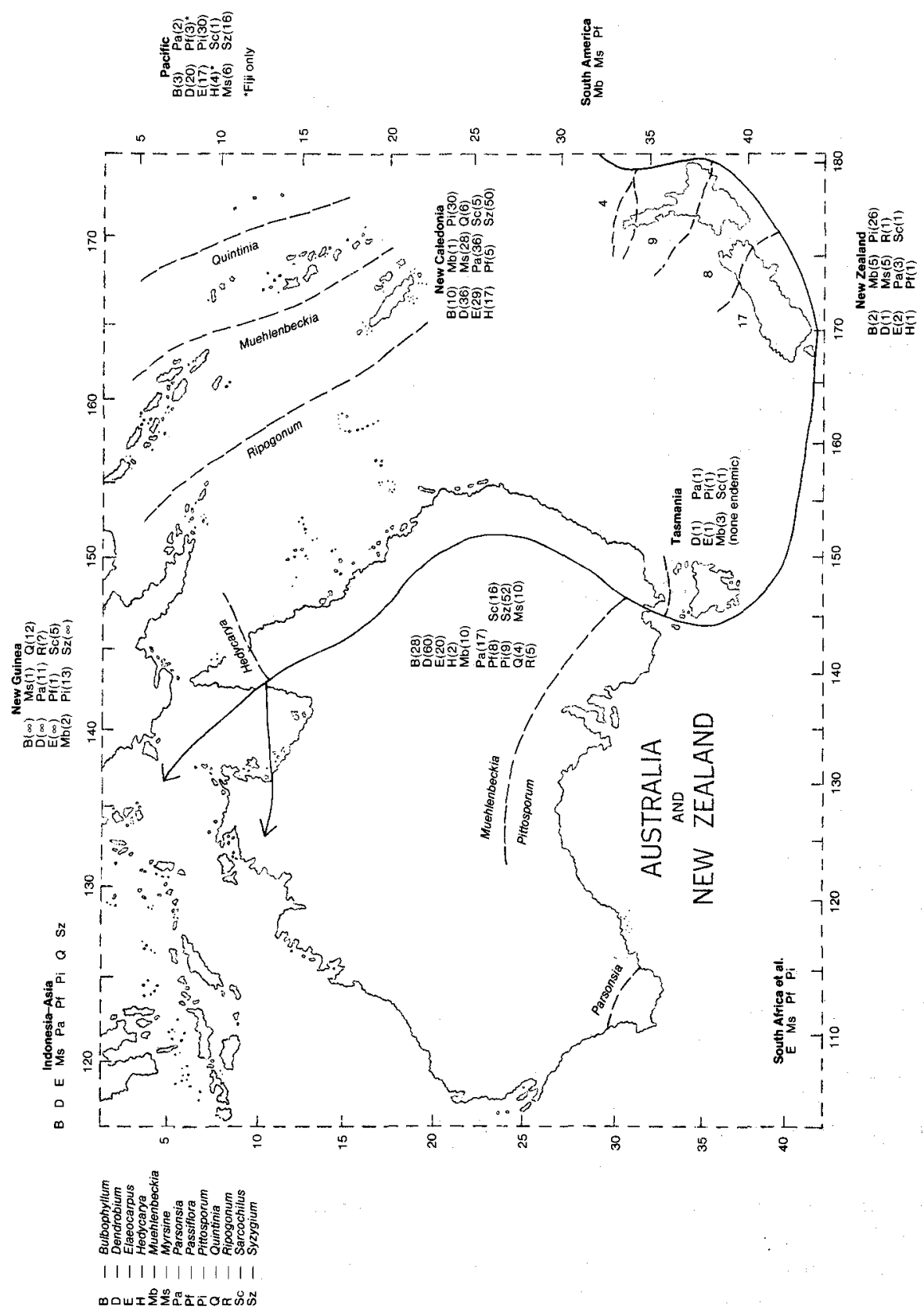

Fig. 4. Distribution of Group 3 angiosperm genera. The numbers adjacent to New Zealand indicate the numbers of species reaching their southern limits in each zone. 
About $60 \%$ of the genera have some oceanic species - Elaeocarpus, Myrsine, Parsonsia, Pittosporum, Syzygium, Bulbophyllum, Dendrobium, Sarcochilus (Drymoanthus)*. The others have no fully oceanic species Hedycarya, Muehlenbeckia, Passiflora, Quintinia, Ripogonum.

As none of the genera has a fossil record in New Zealand extending back to the Cretaceous, the comments on manner of arrival for genera in the preceding section would also apply here.

The South American-Australasian distribution of Muehlenbeckia suggests a southern origin, perhaps in the early Tertiary before Australia and Antarctica separated.

Hedycarya, Parsonsia, Ripogonum and Quintinia are centred in the Australasian region and may have originated there, and Schodde (1972) suggests an Australian origin for Pittosporum. Thus almost half the genera in this group may be of southern origin.

The remaining genera probably originated outside the southern regions, being either widespread in the tropics or centred in tropical Asia.

About a third of the forest species in this group have specialized growth forms. The muehlenbeckias, parsonsias and Ripogonum are twining lianes; Passiflora is a liane climbing by tendrils; Pittosporum kirkii and P. cornifolium are small shrub epiphytes and the four orchids are herbaceous epiphytes.

\section{Group 4. Montane tropical or south temperate angiosperm genera (Fig. 5)}

In this category are 18 genera with 156 New Zealand species, giving an average of 8.5 species per genus. Again, however, if only the 75 forest species are considered the average drops to 4.2 .

The leaf-size groupings for the forest species are:

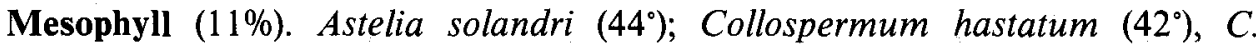
microspermum $\left(41^{\circ}\right.$ ); Coprosma grandifolia (Fig. 3; $42^{\circ}$ ); Griselinia lucida (Fig. $\left.3 ; 46^{\circ}\right)$; Pseudopanax arboreus $\left(46^{\circ}\right)$, P. edgerleyi $\left(47^{\circ}\right)$, P. laetus $\left(39^{\circ}\right)$.

Notophyll (28\%). Aristotelia serrata $\left(47^{\circ}\right)$; Clematis paniculata $\left(47^{\circ}\right)$; Coprosma lucida $\left(47^{\circ}\right), C$. macrocarpa $\left(37^{\circ}\right), C$. robusta $\left(45^{\circ}\right)$, C. tenuifolia $\left(40^{\circ}\right)$; Griselinia littoralis $\left(47^{\circ}\right)$; Melicytus macrophyllus $\left(38^{\circ}\right)$, M. ramiflorus $\left(47^{\circ}\right)$; Metrosideros excelsa $\left(38^{\circ}\right)$; Mida salicifolia $\left(41^{\circ}\right)$; Olearia albida $\left(38^{\circ}\right), O$. macrodonta $\left(46^{\circ}\right), O$. rani $\left(42^{\circ}\right)$; Pseudopanax chathamicus $\left(44^{\circ}\right), P$. colensoi $\left(47^{\circ}\right), P$. crassifolius $\left(47^{\circ}\right), P$. ferox $\left(46^{\circ}\right), P$. lessonii $\left(39^{\circ}\right)$, P. simplex $\left(51^{\circ}\right) ;$ Rubus cissoides $\left(47^{\circ}\right)$.

Microphyll (36\%). Ascarina lucida $\left(47^{\circ}\right)$; Carpodetus serratus $\left(47^{\circ}\right)$; Clematis foetida $\left(46^{\circ}\right), C$. forsteri $\left(41^{\circ}\right) ; C$. parviflora $\left(40^{\circ}\right)$; Coprosma arborea $\left(38^{\circ}\right), C$. chathamica $\left(44^{\circ}\right)$, C. foetidissima $\left(51^{\circ}\right)$, C. spathulata $\left(37^{\circ}\right)$; Fuchsia excorticata $\left(51^{\circ}\right), F$. perscandens $\left(42^{\circ}\right) ;$ Laurelia novaezelandiae $\left(46^{\circ}\right) ;$ Metrosideros (subgenus Mearnsia) albiflora $\left(38^{\circ}\right), M$. (M.) fulgens $\left(44^{\circ}\right), M$. (M.) parkinsonii $\left(42^{\circ}\right)$; Metrosideros robusta $\left(42^{\circ}\right), M$. umbellata $\left(51^{\circ}\right)$; Olearia arborescens $\left(47^{\circ}\right)$, O. paniculata $\left(45^{\circ}\right)$, O. traversii $\left(44^{\circ}\right)$; Plagianthus betulinus $\left(47^{\circ}\right)$; Pseudopanax discolor $\left(37^{\circ}\right)$, P. gilliesii $\left(36^{\circ}\right)$; Rubus schmidelioides $\left(47^{\circ}\right), R$. squarrosus $\left(47^{\circ}\right)$; Weinmannia racemosa $\left(47^{\circ}\right)$, W. silvicola $\left(38^{\circ}\right)$.

* The wider generic view is followed here. 


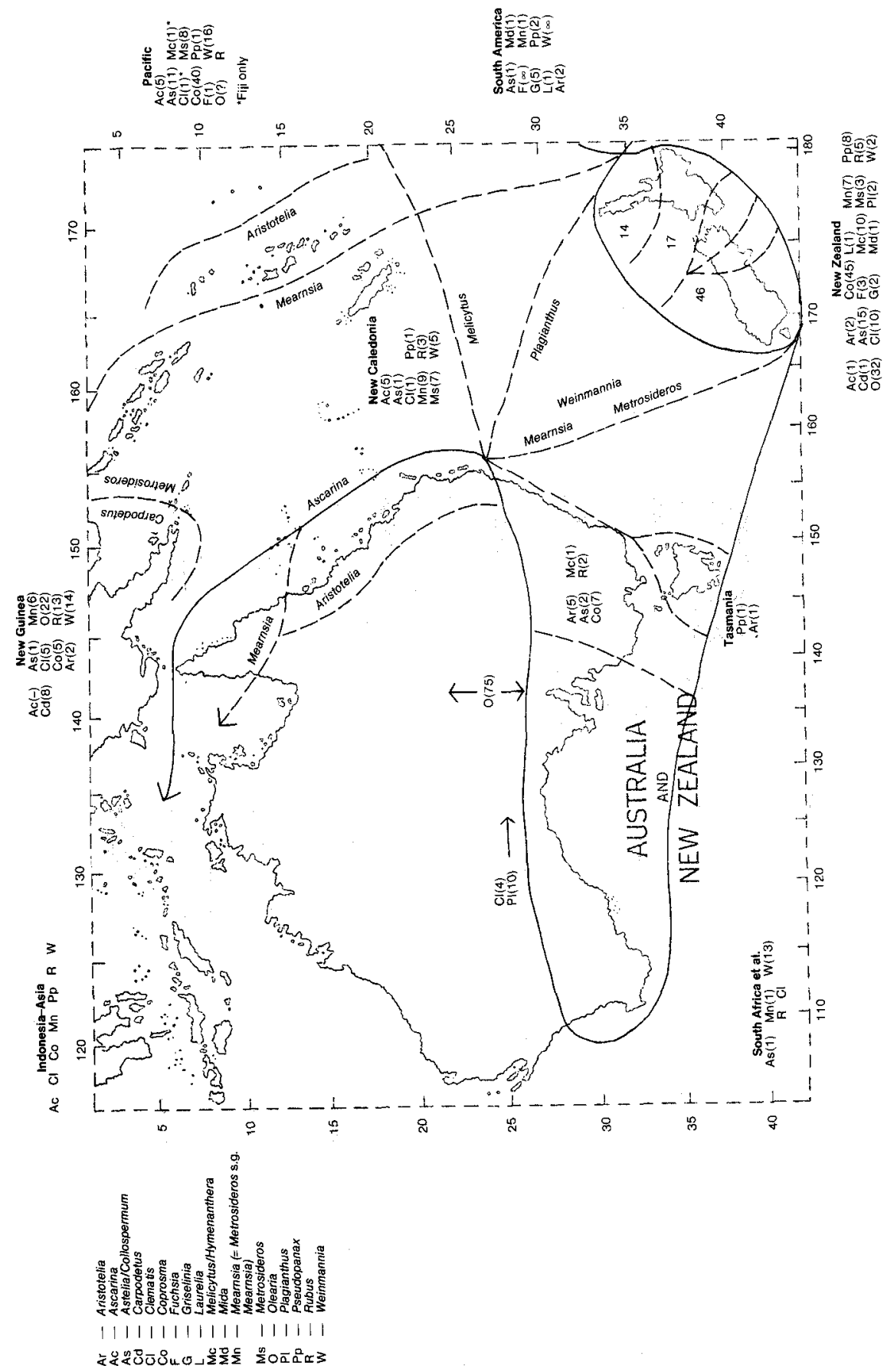

Fig. 5. Distribution of Group 4 angiosperm genera. The numbers adjacent to New Zealand indicate the numbers of species reaching their southern limits in each zone. 
Nanophyll (17\%). Coprosma areolata $\left(47^{\circ}\right)$, C. banksii $\left(47^{\circ}\right)$, C. ciliata $\left(51^{\circ}\right), C$. dodonaeifolia $\left(36^{\circ}\right)$, C. linariifolia $\left(46^{\circ}\right)$, C. rigida $\left(46^{\circ}\right)$, C. rotundifolia $\left(47^{\circ}\right)$; Metrosideros (subgenus Mearnsia) carminea $\left(39^{\circ}\right), M$. (M.) colensoi $\left(42^{\circ}\right), M$. (M.) diffusa $\left(47^{\circ}\right), M$. (M.) perforata $\left(44^{\circ}\right)$; Melicytus micranthus (46 $\left.{ }^{\circ}\right)$; Rubus australis $\left(47^{\circ}\right)$.

Leptophyll (8\%). Aristotelia fruticosa $\left(47^{\circ}\right)$; Coprosma crassifolia $\left(46^{\circ}\right), C$. microphylla $\left(40^{\circ}\right)$, C. parviflora $\left(46^{\circ}\right)$, C. rhamnoides $\left(47^{\circ}\right)$, C. virescens $\left(46^{\circ}\right)$.

On average, leaf size is comparable to that of the Group 3 species, the presence of some mesophylls, not found in Group 3, being counterbalanced by a greater proportion of leaf sizes smaller than microphyll.

There seems to be a larger proportion of species tolerant of cooler conditions in this group, with $53 \%$ extending to the southern end of the country, (five species continuing further to the Auckland Islands at $51^{\circ} \mathrm{S}$ ), compared with $40 \%$ for Group 3 and only $20 \%$ for Group 2.

With forest species of genera of this group there seems to be no clear correlation between decreasing leaf size and increasing latitude. In some of the genera, leaf size is fairly uniform; with others, in view of their general tolerance of coolness, there may not be sufficient reduction in temperature latitudinally to bring about any segregation.

Altitudinally, temperature reduction is greater and in Aristotelia, Griselinia and Pseudopanax the smaller-leaved species extend to higher altitudes than the larger-leaved species. If species above the tree-line are taken into account, then in Astelia most, but not all, of the alpine species have much smaller leaves than those of the forests, and in Coprosma all the higher altitude species except one have very small leaves. In the latter genus, however, there is also quite a strong representation of small-leaved species in the lower altitude forests.

About half the genera have some oceanic species - Ascarina, Astelia, Coprosma, Fuchsia, Metrosideros, Olearia, Pseudopanax, Weinmannia, Mida, Rubus. Those without oceanic species are Aristotelia, Carpodetus, Clematis, Griselinia, Laurelia, Metrosideros s.g. Mearnsia, Melicytus and Plagianthus. A number of these genera or their families have a record back to the early Tertiary in New Zealand but, apart perhaps for Ascarina recorded from the late Cretaceous, a dry land route from Australia-Antarctica does not seem likely.

The present distributions of all genera except Clematis and Rubus suggest a southern origin for them. Clematis and Rubus are almost cosmopolitan and they may ultimately derive from the northern hemisphere. Thus about $90 \%$ of the genera in this group probably originated in the southern hemisphere. Again, about a third of the forest species have specialized growth forms. Of the lianes, the six species of Metrosideros subgenus Mearnsia are root climbers, the Clematis species climb with twining petioles, the Rubus species by thorns and Fuchsia perscandens by long flexuous stems. Metrosideros robusta and sometimes $M$. umbellata are large 'strangling' epiphytes and Pseudopanax arboreus is often a smaller epiphyte of similar form on tree ferns; the two weinmannias often begin life as low epiphytes on tree ferns; Griselinia lucida and sometimes G. littoralis and Pseudopanax colensoi are hemi-epiphytes; Coprosma lucida is sometimes a small shrub epiphyte; and Collospermum hastatum, C. microspermum and Astelia solandri are specialized nest epiphytes. 


\section{Group 5. Genera endemic to New Zealand or of uncertain status or relationships}

Alseuosmia (Alseuosmiaceae, formerly included in Caprifoliaceae). Four species of forest floor shrubs, mostly North Island; related to Memecylanthus and Pachydiscus of New Caledonia; three species notophyllous, one nanophyllous.

Dactylanthus (Balanophoraceae). Monotypic root parasite, North Island; related to Hachettea of New Caledonia.

Earina (Orchidaceae). Close to Epidendrum of Tropical Ameria; two epiphytic species throughout New Zealand; microphyllous; other species in New Caledonia and other Pacific islands.

Elingamita (Myrsinaceae). Monotypic; Three Kings Islands; related to Tapeinosperma; mesophyllous.

Ixerba (Escalloniaceae). Monotypic; small tree in north of North Island; notophyllous.

Knightia (Proteaceae). One tree species common through North Island; related to Eucarpha of New Caledonia, formerly included in Knightia; notophyllous.

Lophomyrtus (Myrtaceae). Two species, formerly included in Myrtus; one nanophyllous (mostly North Island) and one leptophyllous (throughout).

Neomyrtus (Myrtaceae). Monotypic; also formerly in Myrtus; leptophyllous; throughout New Zealand.

'Mistletoes.' Parasites of the family Loranthaceae in New Zealand are microphyllous shrubs, most of which range widely through the country. Formerly, four species were assigned to Elytranthe, one to Loranthus and one to the endemic Tupeia. Elytranthe and Loranthus are large mostly tropical genera. Barlow (1966) revised the Loranthaceae of Australasia and while maintaining Tupeia, established four new endemic New Zealand genera for the other species - Ileostylus (one species), Alepis (one species), Peraxilla (two species), Trilepidea (one species).

Nestegis (Oleaceae). Four species mostly North Island; formerly included in Olea; uncertain whether genus should be regarded as restricted to New Zealand or should include species from south-east Australia, New Caledonia and Hawaii; two species notophyllous, two microphyllous.

Pseudowintera (Winteraceae). Three species, two fairly widespread; notophyllous, microphyllous and nanophyllous.

Rhabdothamnus (Gesneriaceae). Monotypic but with related genera in New Caledonia and Lord Howe Island; undershrub in North Island forests; microphyllous.

Rhopalostylis (Palmae). One species North Island and northern parts of South Island as well as Chathams, second species Kermadecs and a third Norfolk Island; macrophyllous.

Senecio/Brachyglottis (Compositae). Many herbaceous and woody species in New Zealand; of the latter one is a shrub epiphyte, another a liane and a few are small forest shrubs or trees. There is some doubt whether Brachyglottis should be separated from Senecio and it is difficult to locate information on woody forest senecios elsewhere. Forest species mesophyllous to microphyllous. 
Toronia (Proteaceae). Monotypic; northern North Island; formerly included in Persoonia, which has many species in Australia; notophyllous.

The endemic genera in this group may have originated in New Zealand, may have survived only in New Zealand or, in the light of future research, may lose their endemic status.

The present southern or largely southern distribution of the families of Alseuosmia, Ixerba, Knightia, Pseudowintera and Toronia suggests a southern origin for these genera. The families of the remaining genera have wider tropical and/or north temperate distributions, but probably most of the genera are of southern, if not New Zealand origin.

Pseudowintera has a record back to the Upper Cretaceous in New Zealand, so it could have arrived overland on Gondwanaland. The same could be true for Knightia and Toronia or their ancestors, as the family Proteaceae is an old one in the southern hemisphere. The other genera or their ancestors, whose families are not so ancient, probably reached New Zealand after it became isolated.

\section{CONCLUSIONS}

If the three groups of non-endemic angiosperm genera are compared in the order given, the following trends emerge:

(a) Average number of forest species per genus

Group 2*(1.4) Group 3* (3) Group 4* (4.2)

(b) Forest species with microphylls or smaller leaves

Group 2 (32\%) Group $3(62 \%) \quad$ Group $4(61 \%)$

(c) Forest species extending to the far south of New Zealand

Group $2(20 \%) \quad$ Group $3(40 \%) \quad$ Group $4(53 \%)$

(d) Non-forest species

Group $2(0 \%) \quad$ Group $3(28 \%) \quad$ Group $4(48 \%)$

(e) Genera of probable southern origin

Group $2(27 \%)$ Group $3(39 \%) \quad$ Group 4 (90\%).

If it is true that the genera of Group 2 are primarily adapted to tropical lowland conditions then these trends would be expected. The last trend to be considered, however, seems to run counter to the others:

(f) Liane and epiphyte species

Group $2(16 \%) \quad$ Group $3(32 \%)$ Group $4(36 \%)$.

Thus the groups with greater tolerance of lower temperatures and with the strongest representation of southern genera also have a higher proportion of the specialized growth forms generally considered to be characteristic of and largely confined to tropical rainforest.

An explanation for this could be that the vine and epiphyte habits represented in groups 3 and 4 evolved in southern latitudes in genera of southern origin at times during the Tertiary when rainforests were widespread in middle latitudes of both hemispheres. The smaller leaf sizes of most New Zealand vines and epiphytes may reflect less than tropical conditions in mid-latitudes during the Tertiary or may have evolved later in response to the cooler climates of the Pleistocene.

* Group 2 - lowland tropical genera; Group 3 - lowland to montane tropical genera; Group 4 montane tropical or south temperate genera. 
The fact that middle-latitude rainforest distinguished by an abundance of lianes and vascular epiphytes has survived better in New Zealand than elsewhere may be explained by New Zealand's narrow landmass providing a strongly oceanic climate, which would have enabled many rainforest taxa to survive in favourable sites through the Pleistocene glaciations.

\section{REFERENCES}

Barlow, B. A. (1966). A revision of the Loranthaceae of Australia and New Zealand. Austral. J. Bot. 14: 421-499.

Dawson, J. W. (1962). The New Zealand lowland podocarp forest. Is it subtropical? Tuatara 9: 98-116.

Dawson, J. W. (1966). Vegetative features of Griselinia lucida. A New Zealand shrub epiphyte. Tuatara 14: 121-129.

Dawson, J. W. (1967). A growth habit comparison of Metrosideros and Ficus. Tuatara 15: 16-24.

Dawson, J. W. (1970). Rainforests and Gondwanaland. Tuatara 18: 94-95.

Dawson, J. W. \& Sneddon, B. V. (1969). The New Zealand rainforest. A comparison with tropical rainforest. Pacific Sci. 131-147.

Laubenfels, D. J. de (1969). A revision of the Malesian and Pacific rainforest conifers, I. Podocarpaceae, in part. J. Arnold Arbor. 50: 274-369.

Laubenfels, D. J. de (1972). 'Flore de la Nouvelle-Calédonie et Dépendances' (Muséum National d'Histoire Naturelle: Paris) vol. 4, Gymnospermes.

McGlone, M. S. \& Webb, C. J. (1981). Selective forces influencing the evolution of divaricating plants. New Zealand J. Ecol. 4: 20-28.

Mildenhall, D. M. (1980). New Zealand Late Cretaceous and Cenozoic plant biogeography: a contribution. Palaeogeogr. Palaeoclimatol. Palaeoecol. 31: 197-233.

Quinn, C. J. (1982). Taxonomy of Dacrydium Sol. ex Lamb. emend. de Laub. (Podocarpaceae). Austral. J. Bot. 30: 311-320.

Schodde, R. (1972). A review of the family Pittosporaceae in Papuasia. Austral. J. Bot. Suppl. 3: 1-60.

Webb, L. J. (1959). A physionomic classification of Australian rainforests. $J$. Ecol. 47: 551-570. 